\title{
Utility of Remotely Sensed Imagery for Assessing the Impact of Salvage Logging after Forest Fires
}

\author{
Sarah A. Lewis ${ }^{1}$, Peter R. Robichaud ${ }^{1, *}$, Andrew T. Hudak ${ }^{1}$, Brian Austin ${ }^{2}$ and \\ Robert J. Liebermann ${ }^{1}$
}

1 Rocky Mountain Research Station, US Department of Agriculture, Forest Service, Moscow, ID 83843, USA; E-Mail: sarahlewis@ fs.fed.us (S.A.L.); ahudak@fs.fed.us (A.T.H.); rjliebermann@fs.fed.us (R.J.L.)

2 Department of Forest, Rangeland, and Fire Sciences, University of Idaho, Moscow, ID 83844, USA; E-Mail: bdaustin@uidaho.edu

* Author to whom correspondence should be addressed; E-Mail: probichaud@fs.fed.us; Tel.: +1-208-883-2349; Fax: +1-208-883-2318.

Received: 1 February 2012; in revised form: 4 July 2012 / Accepted: 5 July 2012 /

Published: 13 July 2012

\begin{abstract}
Remotely sensed imagery provides a useful tool for land managers to assess the extent and severity of post-wildfire salvage logging disturbance. This investigation uses high resolution QuickBird and National Agricultural Imagery Program (NAIP) imagery to map soil exposure after ground-based salvage operations. Three wildfires with varying post-fire salvage activities and variable ground truth data were used to evaluate the utility of remotely sensed imagery for disturbance classification. The Red Eagle Fire in northwestern Montana had intensive ground truthing with GPS-equipment logging equipment to map their travel paths, the Tripod Fire in north central Washington had ground truthed disturbance transects, and the School Fire in southeastern Washington had no salvage-specific ground truthing but pre-and post-salvage images were available. Spectral mixture analysis (SMA) and principle component analysis (PCA) were used to evaluate the imagery. Our results showed that soil exposure (disturbance) was measureable when pre-and post-salvage QuickBird images were compared at one site. At two of the sites, only post-salvage imagery was available, and the soil exposure correlated well to salvage logging equipment disturbance at one site. When ground disturbance transects were compared to NAIP imagery two years after the salvage operation, it was difficult to identify disturbance due to vegetation regrowth. These results indicate that soil exposure
\end{abstract}


(ground disturbance) by salvage operation can be detected with remotely sensed imagery especially if the images are taken less than two years after the salvage operation.

Keywords: QuickBird; NAIP; School Fire; Red Eagle Fire; Tripod Fire; spectral mixture analysis

\section{Introduction}

Salvage harvest is a means of recovering value from burned timber before it decays and loses value. After wildfires, salvage logging may be initiated to offset the cost of fire suppression activities by recovering a portion of the monetary value of the timber. Economics and land ownership are factors land managers often consider before post-fire logging [1]. Privately owned land may be salvaged immediately after the fire based on the owners discretion; however, a significant percentage of forested land in the western United States is federal or state public land. There are numerous legal steps (Environmental Impact Statements (EIS), potential lawsuits) that must be completed or resolved before harvest activities can commence. These procedures may delay salvage operations months or even years depending on the environmental factors at risk and the potential opposition to the harvest activity [1].

A key part of an environmental assessment is the prediction of disturbance to soil, vegetation, terrestrial and aquatic systems based on local factors, previous harvest outcomes, and related information. When determining the scale and intensity of the timber harvest, ecological considerations include the effect of the logging operation on soils, aquatic and terrestrial habitat, and vegetation succession [2-6]. The effects of wildfire on soil and aquatic systems are well documented [7-9] as are the effects of stand-alone logging operations on individual ecosystem components such as birds, insects and plants [10]. However, there are few studies that have considered the cumulative disturbance of post-fire logging $[6,11,12]$.

Large, severe wildfires generally remove a significant percentage of the organic forest floor layers leaving the forest soils susceptible to erosion and runoff via wind and water [8,13]. The risk of elevated sediment yields are generally the greatest in the first several years after the fire [14] until the natural vegetation has an opportunity to reestablish. During this immediate post-fire period, there is a high probability of accelerated erosion and runoff events because of the removal of the protective organic forest floor layers and the potential alteration of soil structure and infiltration capabilities $[7,9,15,16]$.

Logging operations can have similar effects on the forest floor as a high severity wildfire $[17,18]$. Logging equipment disturbs the forest soils, removes organic material, and compact the soil which can reduce infiltration [6,12]. The degree of disturbance depends on the intensity of the harvest (trees removed per unit area), the type of logging (ground-based or helicopter), and the type of logging equipment used [19,20]. Rubber tire skidders have a reduced surface area to distributed load compared to track skidders, and often create significant ruts in the harvest trail system. Because it is preferable to operate skidders to cover as much ground as possible in the forward direction, rubber tire skidders often leave characteristic turn-around rutting. Compared to rubber tire skidders, track skidders distribute the load over a greater surface area thus reduce rutting. When track skidders are used for side-hill skidding (parallel to the contour) however, ruts may develop as with rubber tire skidders. As 
the track skidders are slower in transit than the rubber tire skidders, it is often just as efficient to run the skidder backwards instead of turning around to get another load of logs. Depending on ground slope, both skidder types may turn around at felled trees which distribute the skidder turn-around rutting to multiple locations.

Soil disturbance from logging may be compounded when a wildfire precedes the harvest [2]. The effect of time between fire and harvest is an undetermined factor; preliminary results from the 2005 School Fire in Washington suggest that salvage logging in the first or second post-fire year 'resets' the disturbance level back to the year of the fire [21]. However, the effects of salvage logging in later years (up to 6 years post-fire) are more ambiguous and dependent on the degree of soil and vegetation recovery since the fire. Anecdotal evidence suggests that salvage logging seems to create a 2 to 3 year delay in vegetation recovery compared to similarly burned but unlogged sites.

Remote sensing is an appealing tool to quantify soil disturbance from salvage logging because of the potential for relatively cheap and accurate "snapshots" of pre-fire, post-fire, and post-harvest conditions. In order to consistently resolve features of interest with remotely sensed imagery, the target patch should be at least 4 times the size of the pixel [22]. Other studies suggest that the smallest mappable vegetation (or soil) patch is $40 \mathrm{~m}^{2}$, which would require, conservatively, imagery of 3-m resolution to resolve. This means the exposed soil patches would need to be 6-7 m across to reliably map. These are fairly large patches, and are much more likely to be found soon after a major disturbance (i.e., wildfire or logging).

High spatial resolution imagery such as collected by the QuickBird satellite (Digital Globe Inc., Longmont, CO, USA) and by the U.S. Department of Agriculture, National Agricultural Imagery Program (NAIP) can provide a clear picture of ground conditions after the fire that is similar in quality and scale to a traditional aerial photograph [23] but with the advantages of greater spectral information and digital format, which allows for more advanced and automated image processing techniques.

QuickBird imagery has been used to help guide post-fire treatments, determine immediate post-fire tree mortality, and refine soil burn severity maps [24,25]. These high-spatial-resolution images are likely to be most useful when identifying spectrally distinct objects: vegetation patches, roads, large patches of soil or ash, or bodies of water, and allow users to assess the color and char condition (green, brown, or black) of remaining vegetation and soil. These characteristics make it well-suited for mapping disturbances from fire and salvage logging.

NAIP imagery is acquired by the federal government through independent contractors and is generally collected via aircraft mounted sensors, but in the future may also be from satellite sensors. Imagery is acquired during the agricultural growing seasons in the continental U.S. and is available to government agencies and the public at no cost.

Another key consideration when using remotely sensed imagery to detect change is the spatial and temporal accuracy of the pre- and post-disturbance images. Accurate change detection between multi-date images is possible only if images are properly geo-registered because it is the areas within the image(s) that display little correlation that indicate the greatest change. This is often difficult because of different sensor radiometric calibration characteristics and changes in atmospheric and illumination conditions that exist between the two images that can confound efforts to isolate changes of interest in the scene, such as changes in soil and vegetation moisture content or changes in land (ground) cover. 
Successful mapping of exposed mineral soil using spectral mixture analysis (SMA) of hyperspectral imagery has been done following the 2002 Hayman wildfire in Colorado [26] and the 2003 Simi and Old Fires in California [27]. SMA is based on the assumption that the observed reflectance signal from a given image pixel is a function of the relative proportions of surface component materials found in the pixel, and to a lesser extent its immediate neighboring pixels [28-31]. Spectra of these component materials in pure form are termed 'endmembers' that can be defined from image pixels considered to be spectrally pure or from spectroradiometer measures of the pure material collected in the laboratory or field. Algorithmically, SMA estimates sub-pixel cover fractions of the component endmembers that when summed together would produce the pixel spectrum observed in the image. The sum of these cover fractions is usually assumed to be linear and constrained to equal one [28,29,32]. The number of SMA output bands equals the number of endmembers supplied to the algorithm, which should be one less than the number of input bands because a degree of freedom is lost in estimating cover fractions of the component materials. SMA requires the input bands be in reflectance units, so it is important that the multispectral image be calibrated to reflectance, especially if multi-date images are to be compared in the analysis.

Identifying forest clearing activity, regeneration following a forest fire, and intensive logging (managing) of forested areas with multi-temporal Landsat images and principal components (PC) analysis (PCA) has been successfully done by others [33]. PCA is a linear transformation of the original pixel coordinates in $n$-dimensional space, where $n$ in the case of a multi-spectral image equals the number of channels. Untransformed image channels are highly correlated. The PC transformation shifts the covariance matrix of the dataset such that correlation is removed [34]. The number of PC output bands equals the number of input bands, with no loss of information. PCA very usefully collapses variance common to all channels, typically $>2 / 3$ of the total variance, into the first principal component (PC1). Higher-order PCs (i.e., PC2, PC3...PCn) thus comprise asymptotically smaller proportions of the total variance, revealing successively subtler features that are often not apparent in the input bands. We used PC analysis because our goal was to identify a general image processing technique for mapping salvage disturbance from high resolution imagery regardless of the source. Since PC analysis is an entirely data dependent method, its application requires no assumptions about sensor radiometric characteristics or calibration. PCA outputs are unitless numbers that cannot be compared between different types of datasets, but it may be possible to compare PCA images of the same type based on the same exact scene to make useful inferences regarding change.

In summary, SMA was our preferred method for mapping exposed mineral soil cover because it estimates it directly. However, properly calibrated QuickBird imagery was not always available, so PCA was selected as an alternative method for mapping exposed mineral soil patterns from NAIP imagery. Our objective was to quantify exposed soil as a surrogate for soil disturbance due to salvage harvest, using SMA or PCA applied to high-resolution QuickBird or NAIP. The three post-fire salvage logging operations selected across the Interior Northwest region span several gradients and variables: low to high intensity harvest, low to high severity wildfire, multiple land ownerships, different equipment types, fire-to-harvest intervals of several months to several years, and salvage to imagery intervals of several to many months. 


\section{Study Areas and Data Sets}

Three study areas were selected for ground and remote soil disturbance analysis where salvage logging and ground-based skidder activity had occurred after wildfires: the 2005 School Fire in southeast Washington, the 2006 Red Eagle Fire in northwestern Montana, and the 2006 Tripod Fire in north-central Washington (Figure 1). Vegetation and soil characteristics and logging techniques and timing varied at the three study areas (Tables 1 and 2).

Figure 1. School Fire, Red Eagle Fire, and Tripod Fire study areas with salvage harvest units (areas) highlighted.

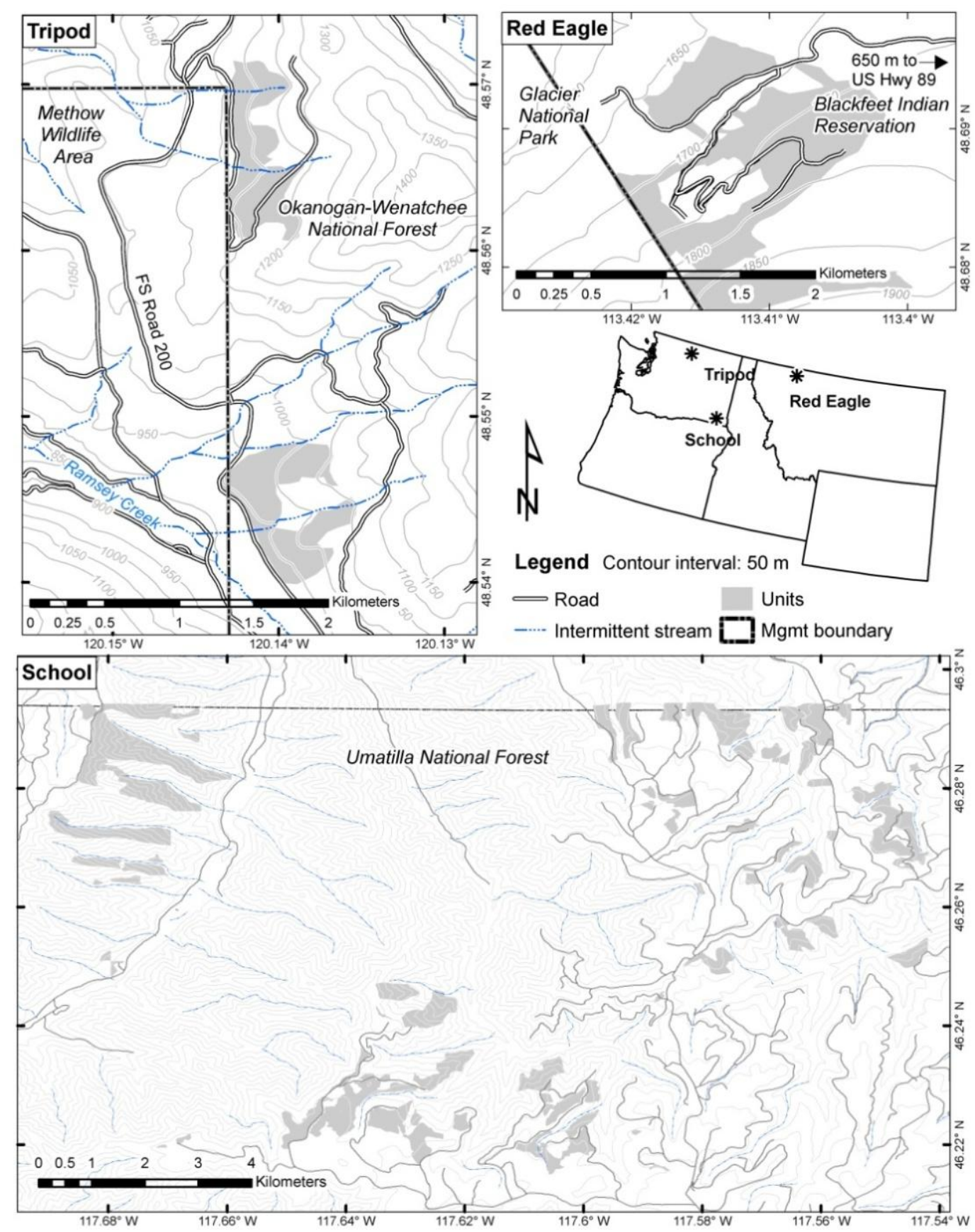


Table 1. Soil and physical characteristics of the study areas. The soil series, taxonomic class, parent material, bulk density and dominant overstory and understory vegetation are provided.

\begin{tabular}{|c|c|c|c|c|c|c|c|c|}
\hline \multirow{2}{*}{$\begin{array}{c}\text { Wildfire } \\
\text { (Elevation, m) }\end{array}$} & \multirow{2}{*}{$\begin{array}{c}\text { Soil Series } \\
\text { (Taxonomic Class) }\end{array}$} & \multirow[t]{2}{*}{ Texture $^{a}$} & \multirow[t]{2}{*}{ Parent Material } & & \multicolumn{2}{|c|}{$\begin{array}{c}\text { Bulk Density } \\
\left(\mathrm{g} \cdot \mathrm{cm}^{-3}\right)\end{array}$} & \multirow[t]{2}{*}{ Overstory Species } & \multirow[t]{2}{*}{ Understory Species } \\
\hline & & & & & $0-5 \mathrm{~cm}$ & $5-10 \mathrm{~cm}$ & & \\
\hline $\begin{array}{l}\text { School } \\
(1500)\end{array}$ & $\begin{array}{c}\text { Klicker } \\
\text { (loamy-skeletal, isotic, frigid } \\
\text { Vitrandic Argixerolls) }\end{array}$ & $\begin{array}{c}\text { ashy } \\
\text { silt loam }\end{array}$ & Basalt & $\begin{array}{l}\text { High } \\
\text { slope } \\
\text { Low } \\
\text { slope }\end{array}$ & 0.93 & 0.78 & $\begin{array}{c}\text { Douglas-fir } \\
\text { (Pseudotsuga menziesii) } \\
\text { Grand fir (Abies } \\
\text { grandis) }\end{array}$ & $\begin{array}{c}\text { Bluebunch wheatgrass } \\
\text { (Psuedorogneria spicata) } \\
\text { Pinegrass (Calamagrostis } \\
\text { rubescens) } \\
\text { Geyers sedge (Carex geyeri) }\end{array}$ \\
\hline $\begin{array}{l}\text { Red Eagle } \\
\quad(1797)\end{array}$ & $\begin{array}{c}\text { Tenex } \\
\text { (loamy-skeletal, mixed, } \\
\text { superactive Spodic } \\
\text { Dystrocryepts) }\end{array}$ & sandy loam & Argillite & & 0.73 & 1.13 & $\begin{array}{c}\text { Lodgepole pine(Pinus } \\
\text { contorta) } \\
\text { Douglas-fir } \\
\text { (Pseudotsuga menziesii) }\end{array}$ & $\begin{array}{c}\text { Grouse whortleberry } \\
\text { (Vaccinium scoparium) } \\
\text { Twinflower (Linnaea borealis) }\end{array}$ \\
\hline $\begin{array}{l}\text { Tripod } \\
(1500)\end{array}$ & $\begin{array}{l}\text { Wapal, Brevco (sandy- } \\
\text { skeletal, isotic, frigid } \\
\text { Vitrandic Haploxerepts) } \\
\text { (loamy-skeletal, isotic, frigid } \\
\text { Vitrandic Haploxerepts) }\end{array}$ & $\begin{array}{l}\text { very stony ashy } \\
\text { coarse sandy } \\
\text { loam }\end{array}$ & $\begin{array}{l}\text { Mixed volcanic ash } \\
\text { over glacial } \\
\text { outwash }\end{array}$ & & 1.31 & 1.0 & $\begin{array}{c}\text { Douglas-fir } \\
\text { (Pseudotsuga menziesii) } \\
\text { Ponderosa pine (Pinus } \\
\text { ponderosa) }\end{array}$ & $\begin{array}{c}\text { Pinegrass (Calamagrostis } \\
\text { rubescens) } \\
\text { Crested wheatgrass } \\
\text { (Agropyron cristatum) }\end{array}$ \\
\hline
\end{tabular}

${ }^{\mathrm{a}}$ U.S. Department of Agriculture Soil Classification System.

Table 2. Salvage harvest date and method, field, and remote sampling information by wildfire.

\begin{tabular}{|c|c|c|c|c|c|c|c|c|}
\hline \multirow{2}{*}{$\begin{array}{c}\text { Wildfire/ } \\
\text { Land Ownership }\end{array}$} & \multirow{2}{*}{$\begin{array}{l}\text { Fire } \\
\text { start }\end{array}$} & \multirow{2}{*}{$\begin{array}{c}\text { Burn } \\
\text { Severity }\end{array}$} & \multirow{2}{*}{$\begin{array}{c}\text { Salvage } \\
\text { Harvest } \\
\text { Date(s) }\end{array}$} & \multirow{2}{*}{$\begin{array}{c}\text { Field } \\
\text { Sampling } \\
\text { Date(s) }\end{array}$} & \multirow[b]{2}{*}{ Equipment Used } & \multicolumn{2}{|c|}{ Imagery [year] } & \multirow[b]{2}{*}{ Image Analysis } \\
\hline & & & & & & Pre-salvage & Post-salvage & \\
\hline $\begin{array}{c}\text { School/ Umatilla National } \\
\text { Forest }\end{array}$ & $\begin{array}{l}\text { August } \\
2005\end{array}$ & $\begin{array}{l}\text { Low } \\
\text { Moderate } \\
\text { High }\end{array}$ & $\begin{array}{c}\text { Fall } 2006 \\
\text { Spring, } \\
\text { Summer } 2007\end{array}$ & $\begin{array}{l}\text { Summer 2006- } \\
2009\end{array}$ & $\begin{array}{l}\text { Track feller buncher, } \\
\text { forwarder }\end{array}$ & $\begin{array}{l}\text { NAIP, QB } \\
\text { [2006] }\end{array}$ & $\begin{array}{l}\text { NAIP, QB } \\
\text { [2009] }\end{array}$ & $\begin{array}{c}\text { PCA - pre- and post- } \\
\text { harvest; SMA - pre- and } \\
\text { post-harvest }\end{array}$ \\
\hline $\begin{array}{c}\text { Red Eagle/ } \\
\text { Blackfeet Tribe }\end{array}$ & $\begin{array}{l}\text { July } \\
2006\end{array}$ & High & $\begin{array}{c}\text { Spring, } \\
\text { summer } 2007\end{array}$ & Summer 2007 & $\begin{array}{l}\text { Track feller buncher, rubber } \\
\text { tire skidder, track skidder }\end{array}$ & - & NAIP [2009] & PCA - post-harvest \\
\hline
\end{tabular}




\subsection{School Fire}

The School Fire was located in southeastern Washington (Figure 1) in mixed forest consisting of grand fir (Abies lasiocarpa), Douglas fir (Pseudotsuga menziesii), and ponderosa pine (Pinus ponderosa). The study areas within the fire were dominated by volcanic (Mount Mazma) ashy surface soils with a mean bulk density between 0.7 and $0.9 \mathrm{~g} \cdot \mathrm{cm}^{-3}$ (Table 1). The 27-year record from the nearest weather station (Touchet Snotel) indicates an annual average precipitation of 1,382 $\mathrm{mm}$, the majority of which falls as snow in the winter months. This climate supports a grand fir and Douglas fir late seral forest (Table 1). Soil burn severities ranged from low to high and salvage units were located across the range of burn severities. Salvage logging began late in the first post-fire year and continued through the fifth post-fire year.

Field data on the School Fire included 79 randomly selected permanent plots established in 2006, stratified by burn severity and planned salvage logging. Where possible, sampling was replicated across the range of pre- and post-fire conditions with more plots in areas burned with moderate and low severity because vegetation response is more variable there [35]. Sample plots were at least 50-m from roads as measured perpendicular to the slope direction, and the center of each plot location was averaged using a Trimble GeoExplorer-series GPS Unit. Burn severity was initially assessed using a Burned Area Response Classification (BARC) map produced by the Remote Sensing Applications Center (RSAC, USDA Forest Service, Salt Lake City, UT, USA). Pre- and post-fire Landsat 5 (TM) images were utilized to calculate the delta Normalized Burn Ratio (dNBR) for burn severity comparisons. Burn severity classes inferred from satellite imagery calculations were ground validated using CBI (Composite Burn Index) during the first two years of sampling [36]. The BARC maps correctly identified $80 \%$ of burn severity designations for 79 plots, as confirmed by the CBI conducted one year post-burn.

Half of the plots in each burn severity category (low, moderate, and high) were placed in locations where post-fire salvage logging was planned. Fifty-six of the plots were salvaged-logged during the winter of 2006-2007 (71\% of all salvaged plots). Of the remaining salvaged plots, 12 plots (14\%) were salvaged between the 2005-2006 growing seasons, 7 plots (9\%) between 2007-2008, and 4 plots (5\%) between the 2008 and 2009. Litigation and weather conditions influenced whether plots were salvaged or not and the timing of the salvage. Extending salvage logging over a four-year timeframe made it difficult to infer definitive changes in vegetation response as a result of salvage, across the range of burn severities.

During field sampling, which was conducted on all plots during June and July of 2006 and 2009, site-specific information was collected to relate the ground conditions to the remotely sensed imagery. Each plot consisted of five subplots, one at center and the others located perpendicular to each other along two axes that ran along and against the aspect of the hillslope. A $1-\mathrm{m}^{2}$ frame was used to ocularly estimate percent ground cover for soil, rock, litter, woody debris, and plant functional types (graminiod, forb, shrub, seedling, and moss/lichen) within each subplot. A photo was taken as an added record of ground cover and vegetation conditions. 


\subsection{Red Eagle Fire}

The 14,000+ ha Red Eagle Fire burned in July and August 2006, straddling the boundary between Glacier National Park and the Blackfeet Indian Reservation in the northern Rocky Mountains (Figure 1). The soils were predominately sandy loam derived from argillite with a mean surface bulk density of $0.73 \mathrm{~g} \cdot \mathrm{cm}^{-3}$ (Table 1). A 31-year record from the nearest weather station (Many Glacier) indicates an annual average precipitation of $1,203 \mathrm{~mm}$, the majority of which falls as snow during the winter months. The burn was intense and resulted in high to moderate soil burn severity over much of the fire. A significant portion of the surface organic layer was completely consumed, and the dense mixed conifer stands of Douglas fir, subalpine fir (Abies lasiocarpa), Englemann spruce (Picea englemannii), and lodgepole pine (Pinus contorta) were largely consumed by crown fire (see: http://www.nrmsc.usgs.gov/science/fire/CBI/r-gnp/redeagle_2.89). The salvage sites were predominately lodgepole pine (Table 1). The Blackfeet Tribe moved rapidly to salvage dead and dying trees, and tribal lands were logged in the first post-fire year (2007) between April and August, with some of the logs yarded over snow. The study area was a single hillslope with high soil burn severity and with a gradient of at least $30 \%$. Percent cover of bare soil, rock, wood, litter and vegetation was estimated using $1-\mathrm{m}^{2}$ point frames at marked locations.

Unique to the Red Eagle Fire, GPS tracking data were available from the harvest equipment. In order to quantify the disturbance from the logging equipment and compare the degree of disturbance depending on equipment type — both rubber tire and track skidders were used on the site. GPS tracking devices were installed on the logging equipment to measure the number of passes over a particular section of ground. The data were cleaned post-harvest to remove errant vertices and overlaps on truck (haul) roads. Integrity was maintained as to the data omissions/commissions for origin, equipment identification, and spatial correctness based on field notes filed and original file dates. The cleaned GPS data were exported to GIS shapefile format which included a count of visible round-trip passes. If the trip was one-way, the count of passes was increased to a full pass (i.e., a one-way trip was rounded up to a full pass) since the number of passes might have been at least one more than recorded due to the resolution of the GPS data. Truck roads within the greater sale area were excluded from this dataset used to validate classification results from the remotely sensed imagery.

\subsection{Tripod Fire}

The 70,000+ ha Tripod Fire burned in north-central Washington (Figure 1), in a dry mixed conifer forest in the summer of 2006. Soils are coarse sandy loams derived from mixed volcanic ash over glacial outwash with a mean surface bulk density of $1.3 \mathrm{~g} \cdot \mathrm{cm}^{-3}$ (Table 1). Average annual precipitation is $300 \mathrm{~mm}$, and vegetation is predominately Douglas fir and ponderosa pine (Table 1). Burn severity across the fire ranged from low to high, but the area of interest for this study was a high burn severity hillslope that was planned for salvage in 2007 but not actually salvage logged until the fall and winter of 2008 (Table 2). Post-logging field sampling was done in 2010 to differentiate ground conditions between skidded trails and undisturbed ground on a single logged hillslope. Three 100-m parallel transects that ran perpendicular to the skid trails on the hillslope were evaluated starting at each endpoint and classified the ground conditions every time segments changed from 'disturbed' to 'undisturbed'. These data were used to validate classification results from the remotely sensed imagery. 


\subsection{Salvage Logging Operations}

Logging equipment and operations differed among sites (Table 2), but feller bunchers were used on all sites to cut and stack burned trees. Forwarders or skidders and de-limbers were used to move the logs from the hillslopes to the staging areas, remove the limbs, and cut the logs to length. The finished logs were piled in a central roadside collection point (landing). The forwarder, using a mechanical claw loader to pick up and place the logs into an open crib, generally moved to and loaded several piles of logs before returning to the landing to unload. The ground contact for the forwarder was rubber tires, and the tractor and crib were supported by four axles. The skidders (two axles) used a grapple hook that clamps onto the ends of up to eight whole trees at once dragging (skidding) them over the ground to the landing. Compared to the forwarder, the skidder caused more ground disturbance as the logs were dragged along the ground surface and more round trips to the landing were needed; however, the forwarder weighed more than skidders and may have caused more soil compaction.

At the School Fire, logs were cut and piled with track feller bunchers, and a rubber tire forwarder was then used to move the logs to a staging area or landing. The end-dates for the different phases of salvage logging operations at the School Fire were 31 October 2006, 20 February 2007, and 27 July 2007. These dates were, respectively, 4, 8, and 13 months after the initial 2006 image acquisition and 2-3 years before the 2009 image acquisition.

At the Red Eagle and Tripod Fires, logging was completed by using feller bunches to cut and pile the logs, and skidders to transport them to landings. On feller buncher trails, logs were cut and piled, and carried in bunches (2-4 logs generally) down or across slope to a staging area where either rubber tire skidders or track skidders yarded the logs to a landing. On the skid trails, logs were dragged in bunches of 3 to $8 \operatorname{logs}$ to landings, necessitating many more logging equipment passes and greater soil disturbance and compaction. Study areas on the Red Eagle and Tripod Fires were salvaged in 2007 and 2008, respectively (Table 2).

\subsection{Remotely Sensed Imagery}

Two types of remotely sensed imagery were collected for this study: QuickBird satellite imagery and NAIP aerial imagery (Table 3). The QuickBird satellite collects four multi-spectral bands and one panchromatic band. The spatial resolution of QuickBird imagery (2.4-m multi-spectral; 0.65-m panchromatic) allows for fine-scale spatial discrimination of ground components in the post-fire environment. QuickBird imagery was acquired for the School Fire on 25 June 2006 (1-yr post-fire, pre-salvage) and 31 July 2009 (4-yr post-fire, majority post-salvage). The imagery was delivered as multiple geotiff files that were combined into a single radiometrically corrected and orthorectified image mosaic. Image accuracy was specified at 23-m at nadir (Digital Globe, Longmont, CO, USA).

NAIP imagery has 1-m or 2-m ground resolution, three visible bands and sometimes a fourth nearinfrared band; however the fourth band was not available at either site (Table 3). NAIP was acquired at a 1-m resolution with a horizontal accuracy within $6 \mathrm{~m}$ of photo-identifiable ground control points. The NAIP imagery timing is dependent on state funding but often occurs on a 3-year cycle, and the Red Eagle and Tripod study areas only had post-fire (also post-salvage) imagery collected in the summer of 2009 (Table 2). 
Table 3. Comparison of remotely sensed image characteristics.

\begin{tabular}{|c|c|c|c|c|c|}
\hline Imagery & Platform & $\begin{array}{c}\text { Spectral Bands Used } \\
\text { [Other Bands Available] }\end{array}$ & $\begin{array}{c}\text { Resolution } \\
\text { (nominal) }\end{array}$ & $\begin{array}{l}\text { Acquisition } \\
\text { Dates }\end{array}$ & Calibration Capabilities \\
\hline QuickBird-2 & $\begin{array}{c}\text { Satellite, } \\
\text { multi- } \\
\text { image } \\
\text { mosaic }\end{array}$ & $\begin{array}{l}\text { Blue, Green, Red, NIR } \\
\text { [Panchromatic] }\end{array}$ & $\begin{array}{c}\text { Panchromatic: } \\
0.65 \mathrm{~m} \\
\text { Multi- } \\
\text { spectral: } 2.5 \mathrm{~m}\end{array}$ & $\begin{array}{l}25 \text { June } 2006 \\
31 \text { July } 2009\end{array}$ & $\begin{array}{l}\text { Radiometric balancing for } \\
\text { multiple scene mosaics and } \\
\text { conversion to top-of- } \\
\text { atmosphere spectral } \\
\text { reflectance; } \\
\text { Orthorectified }\end{array}$ \\
\hline $\begin{array}{c}\text { NAIP } \\
\text { (Montana, } \\
\text { Washington) }\end{array}$ & $\begin{array}{l}\text { Aerial, } \\
\text { multi- } \\
\text { image } \\
\text { mosaic }\end{array}$ & $\begin{array}{c}\text { Blue, Green, Red } \\
\text { [NIR] }\end{array}$ & $1 \mathrm{~m}$ & $\begin{array}{c}10 \text { June-15 } \\
\text { August 2006* }\end{array}$ & Orthorectified \\
\hline
\end{tabular}

\section{Methods}

\subsection{Spectral Mixture Analysis (SMA)}

SMA was used to estimate percent exposed mineral soil from 2006 and 2009 QuickBird imagery of the School Fire. Spectral endmembers for image processing were selected from the most homogenous patches (purest pixels) of green and charred vegetation and soil located in the 2006 QuickBird imagery. By examining the spectral signature of the purest pixels and given our knowledge of the fire area from field sampling, we were able to identify image-derived endmember spectra for spectral mixture modeling. Once endmember spectra were selected, spectral unmixing of individual pixels was used to estimate subpixel fractional cover of the materials on the ground [28,29,32]. Because SMA is performed on a per pixel basis (compared to the scene-wide PCA transform), clipping to the area of interest was not necessary. The outputs of SMA are grayscale fractional cover images that are scaled from 0 to 1 (or 0 to $100 \%$ ) representing relative cover fractions of each input endmember. Any increase in estimated soil exposure between 2006 and 2009 was attributed to disturbance from salvage logging operations.

\subsection{Principal Components Analysis (PCA)}

Principal Component Analysis (PCA) transforms correlated multidimensional data by reducing redundancy or correlation between channels. PCA takes into consideration the spectral response of the entire scene; hence all image data from all fires were clipped to the harvest areas to better isolate the variance due to effects from the harvest operation. This was a simple task at the Red Eagle and Tripod Fires, as the area of interest was a single hillslope at each fire. However, at the School Fire where harvest sites were dispersed, the QuickBird image was clipped to 99 individual harvest units distributed throughout the burned area (Figure 1). Separate PCAs were performed on the exact unit polygons extracted from both the 2006 and 2009 NAIP to allow comparability. Because 2006 and 2009 image dates corresponded to pre- and post-salvage at the School Fire, we compared the PC1 outputs to infer ground cover change. At all three study areas, PC1 contained the overwhelming majority of the variance in the scene $(\sim 98 \%)$. Therefore, PC1 was evaluated as a relative indicator of 
soil disturbance within the scene. We assumed that higher PC values were indicative of higher levels of disturbance due to the harvest operation, and that relatively lower values indicated minimal or no disturbance.

The 2009 NAIP 3-band imagery was clipped to the digitized GPS trails with a 15-m buffer at the Red Eagle Fire. The raster data were then transformed using the ArcGIS principal component analysis tool (ESRI 2011; ArcGIS Desktop: release 9.3.1, Environmental System Research Institute, Redland, CA, USA). The first principal component band (PC1) contained $98 \%$ of the variance in the transformed data set and was used for all further analysis. PC1 was classified as low, moderate, or high disturbance using Jenks natural breaks. The PC1 data was then intersected with the harvest trail data for analysis along with the equipment, pass count, and length of the harvest trail segment.

At the Tripod Fire, the 2009 NAIP 3-band aerial imagery was clipped to a single salvage unit on a uniform hillslope. To test whether the disturbance breaks from the Red Eagle analysis were applicable on another fire; we first applied them to classify the PC1 values at Tripod and compared these classes (low, moderate, high disturbance) to the field data. In the likelihood that the disturbance breaks were site-specific, low, moderate, and high disturbance classes were defined using Jenks natural breaks from this data set alone (independent of the Red Eagle data). These classifications were compared to the field data. At the School Fire, the imagery was clipped to the individual harvest units which were located across the burned area. Only harvest units with no cloud cover and full image coverage were included in the analysis $(n=53)$. Because post-salvage ground-based disturbance data were not available for the School Fire, and because the salvage units were spatially distributed across the landscape (high variance between sites), the PC1 values were not classified but were treated as continuous variables.

\subsection{Statistics}

At the School Fire, correlations were first assessed between the measured soil ground cover at the field plots $(n=79)$ and the soil fractional cover image estimated from SMA of the 2006 and 2009 QuickBird imagery. Correlations were also assessed between the measured soil ground cover and the 2006 and 2009 NAIP PC1 values. In order to evaluate the distinction between soil exposure on cut and uncut units, and any change in soil exposed depending on burn severity class, correlations were assessed by grouping the data into cut/uncut and burn severity classes. Multiple linear regressions with SMA soil exposure in 2006 and 2009 as the dependent variables were performed to test the significance of harvest status, burn severity, harvest intensity, and days between harvest and image acquisition as covariates. At the Red Eagle Fire, correlations were assessed between the number of equipment passes (by skidder type) and the PC1 values using the Pearson and Spearman correlation statistics (SAS proc CORR) (SAS Institute Inc. 2008). All correlations were considered significant if $p<0.05$. To test for significant differences between the magnitudes of disturbance from each type of equipment, a ratio of the PC1 values to number of equipment passes was calculated for both the rubber tire and track skidders. The difference between rubber tire versus track skidder disturbance as indicated by the PC1/number of passes ratio was tested for significance with the Wilcoxon rank sum test [37]. Used as a non-parametric alternative to the student's t-test, the Wilcoxon rank sum test is based on the order in which the observations from the two samples fall. At the Tripod Fire, field transect segments recorded in the field as 'disturbed' or 'undisturbed' were grouped into these two 
classes; the PC1 values intersecting the transects were assigned these same labels and then statistically compared for a significant difference using a student's t-test $(\alpha=0.05)$.

\section{Results}

\subsection{Exposed Soil Change at the School Fire}

\subsubsection{SMA Validation}

The additional field data available at the School Fire allowed for more accurate validation of the SMA results. Across 79 field plots in 2006 there was approximately 17\% green vegetation (23\% on low severity sites, $13 \%$ on high), $26 \%$ non-photosynthetic or senesced vegetation (NPV) (56\% low, $5 \%$ high), $57 \%$ soil exposed ( $21 \%$ low, $82 \%$ high) and $20-25 \%$ of the ground was occluded by canopy cover. The SMA estimated $26 \%$ green vegetation, $45 \% \mathrm{NPV}$ and $29 \%$ soil exposed. Correlation coefficients (Pearson) for the ground cover classes were: green vegetation $(\mathrm{r}=0.60, p<0.0001)$, NPV $(\mathrm{r}=0.41, p=0.0002)$, and soil $(\mathrm{r}=0.16, p=0.15)$. The SMA estimates of green vegetation and NPV both compared accurately to the field data, however, soil exposure was not as well estimated by SMA. This was not an unexpected result, as remotely sensed imagery often images vegetation more accurately than soil because vegetation obstructs the soil from an overhead view [38].

Fifty-three cut salvage units spanning low-moderate-and high burn severity were analyzed for their change in exposed soil before and after the salvage logging operation. Forty-six uncut units were used for recovery comparison during the same time period. In 2006 which was post-fire and pre-salvage, there was an average of $43 \%$ exposed soil on all units regardless if they were eventually cut or not (Table 4).

Table 4. Mean soil exposure and disturbance by salvage cut/uncut and burn severity class from remotely sensed imagery of the School Fire. $n$ is number of units in each class. The Spectral Mixture Analysis (SMA) results from the QuickBird imagery are mean soil exposure (x100\%). The QuickBird and NAIP Principal Component Analysis (PCA) values are continuous PC1 values for comparison.

\begin{tabular}{ccccccccc}
\hline Harvest & Burn & \multicolumn{2}{c}{ QuickBird SMA } & \multicolumn{2}{c}{ QuickBird PCA } & \multicolumn{2}{c}{ NAIP PCA } \\
Status & Severity & $\boldsymbol{N}$ & $\mathbf{2 0 0 6}$ & $\mathbf{2 0 0 9}$ & $\mathbf{2 0 0 6}$ & $\mathbf{2 0 0 9}$ & $\mathbf{2 0 0 6}$ & $\mathbf{2 0 0 9}$ \\
\hline Cut & All & 53 & 0.45 & 0.73 & 405 & 515 & 212 & 160 \\
Cut & Low & 22 & 0.48 & 0.73 & 433 & 499 & 209 & 157 \\
Cut & Moderate & 19 & 0.45 & 0.71 & 403 & 511 & 217 & 152 \\
Cut & High & 12 & 0.40 & 0.76 & 354 & 550 & 212 & 179 \\
Uncut & All & 34 & 0.40 & 0.50 & 391 & 492 & 205 & 130 \\
Uncut & Low & 17 & 0.38 & 0.34 & 411 & 441 & 192 & 114 \\
Uncut & Moderate & 8 & 0.40 & 0.59 & 381 & 527 & 212 & 143 \\
Uncut & High & 9 & 0.41 & 0.71 & 362 & 559 & 222 & 147 \\
\hline
\end{tabular}

In 2009 , there was an average of $73 \%$ exposed soil on the cut units, and only $50 \%$ on the uncut units. The remaining high soil exposure on the uncut units is likely due to uncertainties associated with multi-date image analysis (which should be evenly distributed across the scene) rather than an actual increase in exposed soil. However, the much greater increase in soil exposure on the cut units 
compared to the uncut units can only be explained by actual differential change in the scene, for example pre-salvage and post-salvage (Figure 2).

Figure 2. (a) Pre- and (b) post-salvage QuickBird image from the School Fire showing the change in soil exposure. Harvest units are delineated by a black line. Salvage skid trails are visible in (b) where trees existed in the 2009 image (white linear features).

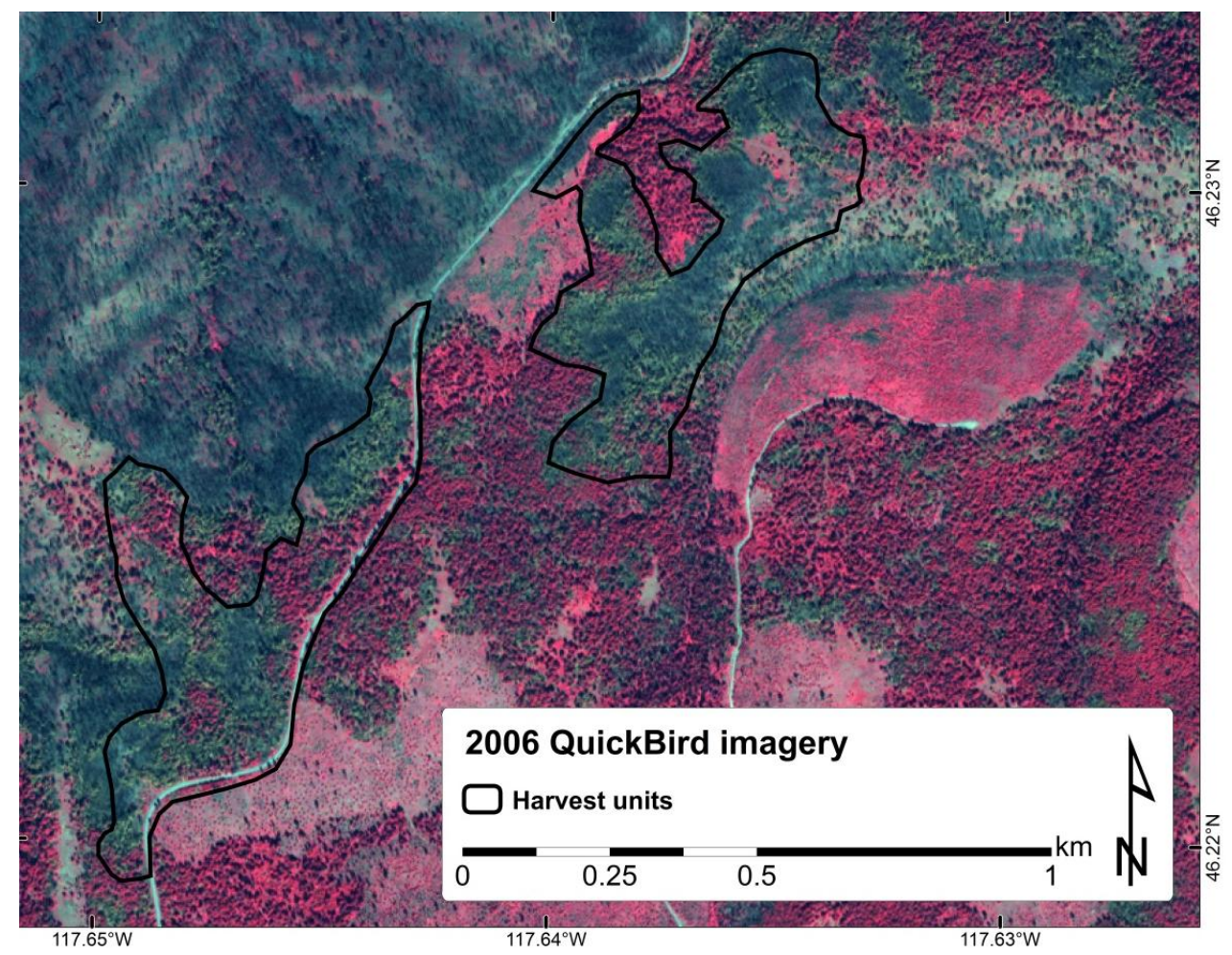

(a)

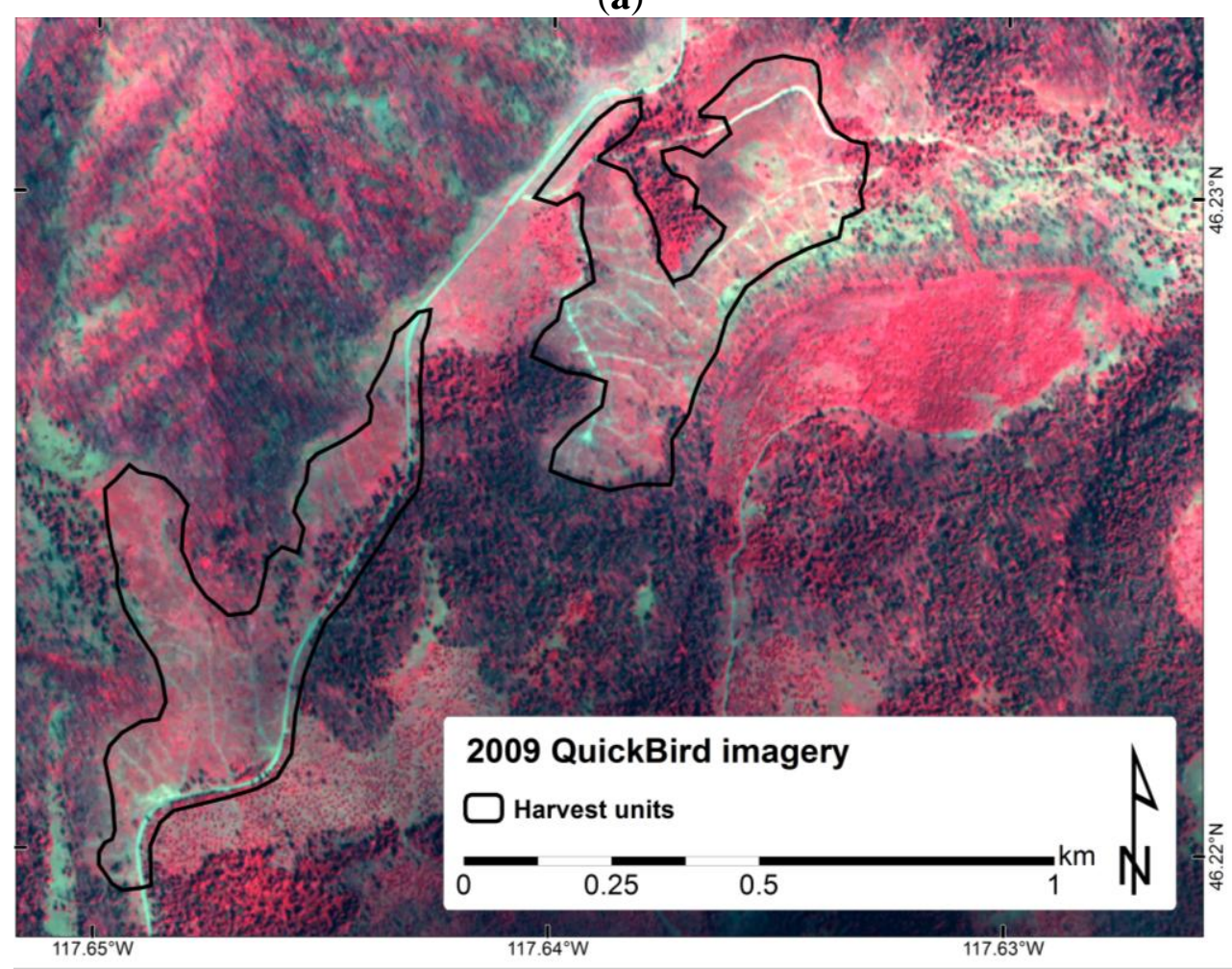

(b) 


\subsubsection{PCA Validation}

Comparison of PC1 values from separate PCAs of the 2006 and 2009 QuickBird imagery showed an increase in soil disturbance similar to the increase in soil exposure found using SMA at the School Fire. Similar PC1 values were found on the cut and uncut units in 2006 (405 and 391, respectively) and greater values were found in 2009 on the cut (515) and uncut units (492) (Table 4). The increase on both the uncut and cut units between 2006 and 2009 is analogous to the results found with the SMA. The increase in predicted disturbance (greater PC1 values) is not due to any physical disturbance on the uncut units, but more likely due to the later date of image acquisition and the drier soil and vegetation conditions. There were significant correlations between the SMA results and the PC1 values in both 2006 (Pearson $\rho=0.68$ ) and 2009 ( $\rho=0.47$ ), suggesting that the PC1 values are indicative of exposed soil in the imagery, but as with the Quickbird image-derived SMA values, the PC1 values did not significantly correlate to field measures of soil exposure.

In contrast, the PC1 values from the PCAs of 2006 and 2009 NAIP did not appear to follow the same trends as those from the QuickBird imagery (Table 4). In 2006, similar PC1 values were found on the cut and uncut units (212 and 205, respectively), however much smaller PC1 values were found in 2009 on both the cut (160) and uncut (130) units. The decrease in PC1 values on both the cut and uncut units was similar in proportion, providing no evidence of slower vegetation recovery due to soil disturbance on cut units. This was somewhat unexpected given the 2-3 year time span following salvage harvest disturbance, which should allow for vegetation recovery.

\subsubsection{Modeling Soil Exposure and Disturbance}

Linear regressions with SMA soil exposure as the dependent variable and harvest status (cut or uncut) and burn severity class as the independent variables showed that units that were eventually cut had slightly more exposed soil in 2006 than units that were not cut (Table 5). Cut units had $20 \%$ more exposed soil in 2009 than uncut units (Table 5). SMA soil exposure was not significantly different by burn severity class in 2006; all sites had slightly more than $40 \%$ soil exposure (Table 5). In 2009, low burn severity sites had significantly less soil exposed $(54 \%)$ than either the moderate or high units (65\% and $74 \%$, respectively). However, burn severity was not a significant covariate in the regression and was dropped from the model. These results also illustrate the over-prediction of soil in the 2009 imagery. There was likely no increase in soil exposure on the low severity units or on the uncut units; however, both were modeled with a $10-15 \%$ increase.

PC values from both the QuickBird and NAIP were also modeled. There was no change in disturbance (PC1 values) between the cut and uncut units in 2006 or 2009 in the QuickBird imagery (Table 5). There were significantly higher PC1 values on the low burn severity sites in 2006 than on the moderate or high burn severity sites; however in 2009, the lowest PC1 values were found on the low burn severity sites although the differences were not significant (Table 5). The PC1 values from the NAIP did not show a significant difference between the cut and uncut units in 2006, and did in 2009. By burn severity class, the low severity units had the lowest PC1 values in both 2006 and 2009 (Table 5). Similar to the SMA data, there were few significant differences by burn severity class, with the most common difference being between the low and high severity classes. 
Table 5. School Fire SMA and PCA regression model results and tests of significance. The model form was: soil exposed or PC1 disturbance $=$ cut $\mid$ burn severity. Same letters $(a, b)$ in a row indicate no significant difference at $\alpha=0.05$.

\begin{tabular}{lccccc}
\hline \multirow{2}{*}{ Image Analysis and Year } & \multicolumn{2}{c}{ Status } & \multicolumn{3}{c}{ Burn Severity } \\
& Cut & Uncut & Low & Moderate & High \\
\hline SMA soil 2006 & $0.44^{\mathrm{a}}$ & $0.40^{\mathrm{b}}$ & $0.43^{\mathrm{a}}$ & $0.42^{\mathrm{a}}$ & $0.41^{\mathrm{a}}$ \\
SMA soil 2009 & $0.74^{\mathrm{a}}$ & $0.55^{\mathrm{b}}$ & $0.54^{\mathrm{b}}$ & $0.65^{\mathrm{a}}$ & $0.74^{\mathrm{a}}$ \\
QB PC 2006 & $397^{\mathrm{a}}$ & $385^{\mathrm{a}}$ & $422^{\mathrm{a}}$ & $392^{\mathrm{b}}$ & $358^{\mathrm{b}}$ \\
QB PC 2009 & $520^{\mathrm{a}}$ & $513^{\mathrm{a}}$ & $475^{\mathrm{b}}$ & $519^{\mathrm{ab}}$ & $555^{\mathrm{b}}$ \\
NAIP PC 2006 & $213^{\mathrm{a}}$ & $208^{\mathrm{a}}$ & $199^{\mathrm{b}}$ & $214^{\mathrm{a}}$ & $217^{\mathrm{a}}$ \\
NAIP PC 2009 & $163^{\mathrm{a}}$ & $134^{\mathrm{b}}$ & $134^{\mathrm{b}}$ & $148^{\mathrm{ab}}$ & $163^{\mathrm{a}}$ \\
\hline
\end{tabular}

Harvest intensity $\left(\mathrm{m}^{3} \cdot \mathrm{ha}^{-1}\right.$ removed from unit) was also found to be a significant predictor of SMA soil exposed (Table 6). Adding harvest intensity to the equation increased the soil exposure predicted on the cut units and decreased the soil exposure predicted on the uncut units (Tables 5 and 6). There was more than double the soil exposure predicted on the cut units (84\%) compared to the uncut units (40\%) in 2009. The regression model with PC1 values from the QuickBird imagery did not indicate a significant decrease in disturbance between cut and uncut units (416 and 377, respectively), while PC1 values from the NAIP did (cut -123, uncut -87) (Table 6). Days between harvest and image acquisition were also tested as explanatory variables but were found to be non-significant in predicting soil exposure.

Table 6. School Fire SMA and PCA regression model results and tests of significance. The model form was: soil exposed or PC1 disturbance $=$ cut $*$ harvest intensity. Same letters in a row $(a, b)$ indicate no significant difference at $\alpha=0.05$.

\begin{tabular}{ccc}
\hline \multirow{2}{*}{ Image Analysis and Year } & \multicolumn{2}{c}{ Status } \\
& Cut & Uncut \\
\hline SMA soil 2009 & $0.84^{\mathrm{a}}$ & $0.40^{\mathrm{b}}$ \\
QB PC 2009 & $416^{\mathrm{a}}$ & $377^{\mathrm{a}}$ \\
NAIP PC 2009 & $123^{\mathrm{a}}$ & $87^{\mathrm{b}}$ \\
\hline
\end{tabular}

\subsection{Soil Disturbance at the Red Eagle and Tripod Fires}

At the Red Eagle and Tripod Fires only post-harvest NAIP was analyzed, making our results simpler and briefer than at the School Fire. Jenks natural breaks at the Red Eagle Fire distributed the PC1 values into three disturbance classes: low 86-233, moderate 234-283, and high 284-385.

At the Red Eagle Fire, we found significant correlations between the PC1 values and the number of equipment passes per pixel, which varied from 1 to 36 . The track skidder had stronger correlations with the PC1 (i.e., disturbance) values (Spearman $\rho=0.33, p<0.0001$ ) than the rubber tire skidder (Spearman $\rho=0.08, p=0.016$ ), and the rubber tire created more disturbance than the track skidder (Figure 3). For all of the map pixels intersected by skidder trails (Figure 4), we also divided the PC1 values by the number of equipment passes to provide a simple ratio (PC1/pass) with which to compare disturbance impact between the rubber tire skidder pixels versus track skidder pixels. A non-parametric Wilcoxon rank sum test [37] between the means of these two non-normal distributions showed that the 
rubber tire skidder disturbance ratio (mean $=172 /$ pass, s.d. $=118 /$ pass, $n=855$ ) was significantly higher $(p<0.0001)$ than the track skidder disturbance ratio (mean $=97 /$ pass, s.d. $=79, \mathrm{n}=730)$.

Figure 3. Red Eagle Fire: disturbance comparison between the rubber tire and track skidders. The boxes represent the upper and lower quartiles and the midline represents the median. The minimum and maximum data values are shown by the caps on the whiskers.

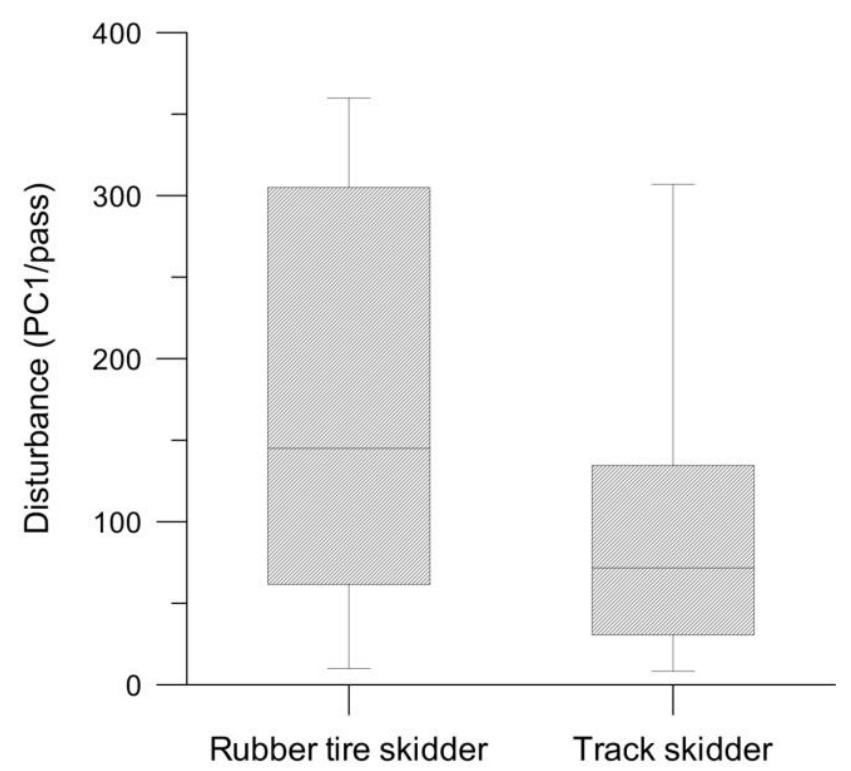

Figure 4. Red Eagle Fire: disturbance classification. The area in green indicates low disturbance $(29 \%)$, yellow indicates moderate disturbance $(44 \%)$, and red indicates high disturbance $(27 \%)$. The area is clipped to a $15-\mathrm{m}$ buffer around the harvest trails (as mapped by GPS tracking devices) and these are shown in black.

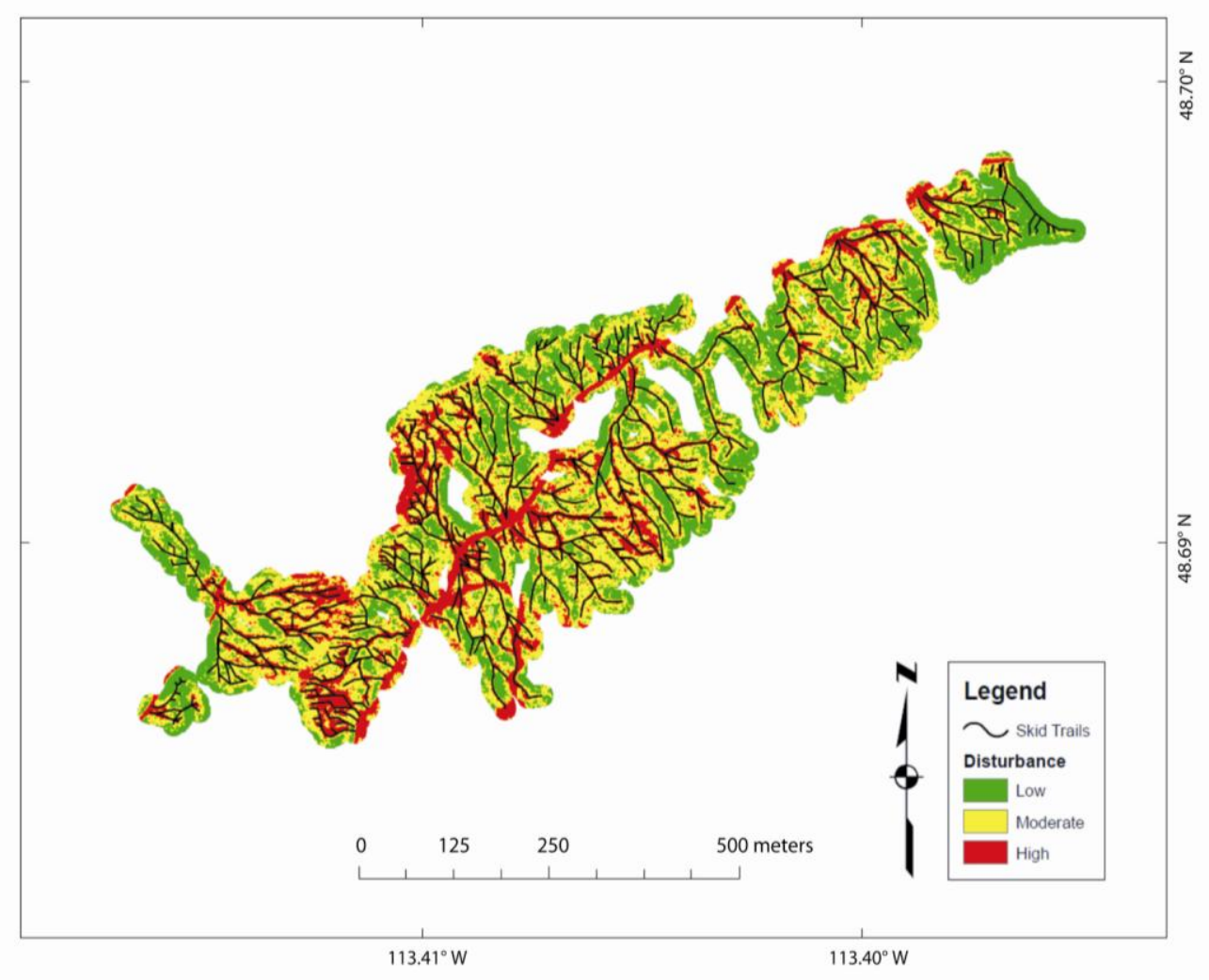


At the Tripod Fire, where the field transects overlaid the PC transformed imagery, the range of PC1 values was 105 to 234; PC1 pixels classified as disturbed ranged from 105 to 229 (mean $=177$, s.d. $=25$, $\mathrm{n}=222$ ) and pixels classified as undisturbed ranged from 140 to 234 (mean = 190, s.d.=25, n = 144). A Student's t-test revealed the difference to be non-significant $(p>0.05)$. It is worthwhile to note the dissimilarity of PC1 values between the Tripod Fire (105-234) and the Red Eagle Fire (86-385).

\section{Discussion}

SMA on the School Fire was moderately successful for detection of ground cover change. The correlations between imaged green vegetation and non-photosynthetic vegetation and the ground data were significant. However, the correlations between the imaged and field-measured soil were not significant which we attribute to occlusion of the soil by the tree overstory canopy. Moreover, the 31 July post-salvage QuickBird image compared to the 25 June pre-salvage QuickBird image entails a vegetation phenology offset that likely confounded the estimate of soil cover change based on SMA results. More senesced ground vegetation in late July than in June would expose more underlying soil, and the spectral signature of senesced vegetation is easily confused with that of soil [29], particularly if using broadband imagery such as QuickBird. Despite this complication, imaged values can be useful for comparing relative proportions and not just absolute percentages on the ground. In this study, nearly 30\% more soil was imaged on the cut units between 2006 and 2009, compared to only 10\% more soil imaged on uncut units during the same period (Table 5, Figure 2). Because there was significantly more soil imaged on the cut units, we can conclude that this is a product of the disturbance from salvage logging, which corroborates a similar finding from a prior study [39].

The PCAs applied to the School Fire QuickBird images produced comparable results to the SMAs. We believe this is because the PCAs were based on exactly the same data extracted from the salvage units distributed across the landscape (i.e., 99 separate PCA runs), which was admittedly an awkward step to undertake but proved worthwhile. Furthermore, it was important that the QuickBird images were consistently atmospherically corrected and calibrated to ensure comparability of reflectance values between the 2006 and 2009 image dates. The NAIP may not have been similarly corrected, nor were they calibrated, and so we must discount the conflicting results obtained by comparing the NAIPbased PCAs at the School Fire.

Single-scene PCA of NAIP on the Red Eagle Fire worked well because the area of interest was confined to a single hillslope and the variance was easily attributed to the salvage logging disturbance. The available ground-truth data from the GPS and equipment tracks were very valuable to confirm that the PC1 values were related to the disturbance, and to classify the disturbance by number of passes and by equipment type. This type of analysis is likely to be most successful under similar conditions of high severity disturbance and a localized area of interest with few confounding sources of disturbance. However, a single multi-temporal PCA including both images could be tested as it has been found to be successful under similar circumstances [40].

The PCA of NAIP collected two years after salvage harvest after the Tripod Fire was ineffective for differentiating significant soil disturbance effects. However, the ground truth data collected at the Tripod Fire were also less powerful than were at the Red Eagle Fire; this was likely another contributing factor to our poor correlations at the Tripod Fire. The differing range of PC1 values found at the Tripod Fire compared to those at the Red Eagle Fire also confirmed our belief that the PC values 
are highly site-specific. Disturbance classifications or comparisons between sites are not possible with PCA alone - field data are essential.

Although our study had mixed ability to test the utility of high-resolution, multispectral imagery for mapping soil effects of salvage logging, we felt that these methods show promise for large scale mapping of disturbance related to salvage operations. Ideally, the imagery would be acquired just before and soon after the salvage operations, and the field data would be collected within days of the image acquisition. However, such is rarely the case with field studies, and the logistics of a groundtruthing campaign often span weeks or months. Potential explanations for inconsistencies between ground and image data include:

- Slope steepness and aspect, which interact with the view angle from the sensor and the sun elevation and azimuth angle in complex but quantifiable ways.

- Site-specific 'albedo' issues such as soil color and senesced vegetation.

- Spatial heterogeneity of the salvage sites - both from spatial variability in post-fire disturbance, spatial variability in salvage logging, and spatial variability in slash being placed after the skidder trails were no longer used — can lead to discrepancies between what was measured on the ground and inferred from the image. Also the influence of previous roads/trails.

- Plot geolocation errors and image georectification errors, which both contribute to errors in models relating field and remotely sensed data. The effect of mosaicing of several images (NAIP) of undocumented dates together likely produce edge-errors.

\section{Conclusions}

Both spectral mixture analysis and principal component analysis of post-harvest imagery were useful to highlight spatial patterns in soil exposure or disturbance due to the post-fire salvage logging. Change detection using pre- and post-harvest QuickBird imagery was most successful when the time lapse between salvage and image acquisition was short enough that revegetation did not significantly change the scene. Principal component analysis of single-scene post-salvage imagery was most successful when detailed ground truth data were available. Because principal component analysis is a data-dependent method, we do not recommend trying to compare separate principal component analysis results between images for change detection even if from the same sensor and collected over the same scene. The appropriate analysis method should be chosen based on the available imagery and ground data. We recommend QuickBird imagery over National Agricultural Imagery Program imagery because of the available calibration qualities of the QuickBird sensor. Atmospheric and radiometric image calibration are especially important for identifying change detection between scenes, and based on our results, change detection was the best method for identifying salvage logging disturbance. If QuickBird or other atmospherically and radiometrically calibrated imagery is unavailable, National Agricultural Imagery Program or similar imagery and principal component analysis may be a sufficient substitute, provided that any inferences are confined to the single image and sufficiently substantiated with ground truth data. Our results encourage further investigation and use of highresolution imagery for research applications and post-fire management. 


\section{Acknowledgements}

This project was supported by the US Department of Agriculture Forest Service and Department of Interior Joint Fire Science Program (JFSP) grants (06-3-4-21 and 06-1-02-03). We are very grateful to the JFSP for providing funding and support throughout the course of this project. This research was also supported in part by funds and personnel from the US Department of Agriculture Forest Service, Rocky Mountain Research Station and the University of Idaho. We thank the Blackfeet Tribe, Umatilla National Forest and the Wenatchee-Okanogan Nation Forest for their logistical support. Funding for QuickBird imagery on the School Fire was provided by the Pomeroy Ranger District, Umatilla National Forest. Two anonymous reviewers provided insightful advice and comments.

\section{References}

1. Prestemon, J.P.; Wear, D.N.; Stewart, F.J.; Holmes, T.P. Wildfire, timber salvage, and the economics of expediency. Forest Policy Econ. 2006, 8, 312-322.

2. Beschta, R. L.; Rhodes, J.J.; Kauffman, J.B.; Gresswell, R.E.; Minshall, G.W.; Karr, J.R.; Perry, D.A.; Hauer, R.; Frissell, C.A. Postfire management on forested public lands of the western United States. Conserv. Biol. 2004, 18, 957-967.

3. Castro, J.; Moreno-Rueda, G.; Hodar, J.A. Experimental test of post fire management in pine forests: impact of salvage logging versus partial cutting and nonintervention on bird species assemblages. Conserv. Biol. 2010, 24, 810-819.

4. Karr, J.R.; Rohodes, J.J.; Minshall, G.W.; Hauer, F.R.; Beschta, R.L.; Frissell, C.A.; Perry, D.A.. The effects of postfire salvage logging on aquatic ecosystems in the American west. BioScience 2004, 54, 1029-1033.

5. Lindenmayer, D.B.; Foster, D.R.; Franklin, J.F.; Hunter, M.L.; Noss, R.F.; Schmiegelow, F.A.; Perry, D. Salvage harvesting policies after natural disturbance. Science 2004, 303, 1303.

6. McIver, J.D.; Starr, L. A literature review of the environmental effects of post-fire logging. West. J. Appl. For. 2001, 16, 159-168.

7. Neary, D.G.; Ryan, K.C.; DeBano, L.F., eds. Wildland Fire in Ecosystems: Effects of Fire on Soils and Water; Gen. Tech. Rep. RMRS-GTR-42-vol.4; Rocky Mountain Research Station, US Department of Agriculture, Forest Service: Ogden, UT, USA, 2005; p. 250.

8. Parsons, A.; Robichaud, P.R.; Lewis, S.A.; Napper, C.; Clark, J.T. Field Guide for Mapping PostFire Soil Burn Severity; Gen. Tech. Rep. RMRS-GTR-243; Rocky Mountain Research Station, US Department of Agriculture, Forest Service: Fort Collins, CO, USA, 2010; p. 49.

9. Shakesby, R.A.; Doerr, S.H. Wildfire as a hydrological and geomorphological agent. Earth-Sci. Rev. 2006, 74, 269-307.

10. Cobb, T.P.; Morissette, J.L.; Jacobs, J.M.; Koivula, M.J.; Spence, J.R.; Langor, D.W. Effects of postfire salvage logging on deadwood-associated beetles. Conserv. Biol. 2011, 25, 94-104.

11. Lindenmayer, D. Salvage harvesting - Past lessons and future issues. For. Chron. 2006, 82, 48-53.

12. Peterson, D.L.; Agee, J.K.; Aplet, G.H.; Dykstra, D.P.; Graham, R.T.; Lehmkuhl, J.F.; Pilliod, D.S.; Potts, D.F.; Powers, R.F.; Stuart, J.D. Effects of Timber Harvest Following Wildfire in Western North America; Gen. Tech. Rep. PNW-GTR-776; Pacific Northwest Research Station, US Department of Agriculture, Forest Service: Portland, OR, USA, 2009; p. 51. 
13. Benavides-Solorio, J.D.; MacDonald, L.H. Measurement and prediction of post-fire erosion at the hillslope scale, Colorado Front Range. Int. J. Wildland Fire 2005, 14, 1-18.

14. Moody, J.A.; Martin, D.A. Initial hydrologic and geomorphic response following a wildfire in the Colorado Front Range. Earth Surf. Proc. Landf. 2001, 26, 1049-1070.

15. DeBano, L.F. The role of fire and soil heating on water repellency in wildland environments: A Review. J. Hydrol. 2000, 231-232, 195-206.

16. Robichaud, P. R. Fire effects on infiltration rates after prescribed fire in northern Rocky Mountain forests, USA. J. Hydrol. 2000, 231-232, 220-229.

17. Lindenmayer, D.; McCarthy, M.A. Congruence between natural and human forest disturbance: a case study from Australian montane ash forests. For. Ecol. Manag. 2002, 155, 319-335.

18. Silins, U.; Stone, M.; Emelko, M.B.; Bladon, K.D. Sediment production following severe wildfire and post-fire salvage logging in the Rocky Mountain headwaters of the Oldman River basin, Alberta. Catena 2009, 79, 189-197.

19. Klock, G.0. Impact of five post-fire salvage logging systems on soils and vegetation. J. Soil Water Conserv. 1975, 30, 78-81.

20. Roberts, M.R. A conceptual model to characterize disturbance severity in forest harvests. For. Ecol. Manag. 2007, 242, 58-64.

21. Robichaud, PR; Lewis, S.A.; Lentile, L.; Morgan, P.; Hudak, A. Invasive Species Response to Fire and Post-Fire Rehabilitation Following the 2005 School Fire, Umatilla National Forest; A Rapid Response Project, (JFSP \# 06-1-02-03); Final Report to the Joint Fire Science Program; Boise, ID, USA, 2010; p. 23.

22. Hamilton, R.; Johnson, V.; Hunt, E.R. Jr.; Gillham, J.; Schrader-Patton, C.; Dewey, S.A.; Everitt, J.H. A Weed Manager's Guide to Remote Sensing and GIS; Rep. No. RSAC-0077; Remote Sensing Applications Center, US Department of Agriculture, Forest Service: Salt Lake City, UT, USA, 2005; Available online: http://www.fs.fed.us/eng/rsac/invasivespecies/ (accessed on 1 August 2011).

23. Goetz, S.J.; Wright, R.; Smith, A.J.; Zinecker, E.; Schaub, E. IKONOS imagery for resource management: tree cover, impervious surface, and riparian buffer analyses in the Mid-Atlantic Region. Remote Sens. Environ. 2003, 88, 195-208.

24. Chirici, G.; Corona, P. An overview of passive remote sensing for post-fire monitoring. Forest 2005, 2, 282-289. Available: http://www.sisef.it/forest/show.php?id=305 (accessed on 1 August 2011).

25. Corona, P.; Lamonaca, A.; Chirici, G. Remote sensing support for post fire forest management. iForest 2008, 1, 6-12. Available online: http://www.sisef.it/iforest/show.php?id=305 (accessed on 1 August 2011).

26. Robichaud, P.R.; Lewis, S.A.; Laes, D.Y.M.; Hudak, A.T.; Kokaly, R.F.; Zamudio, J.A. Postfire soil burn severity mapping with hyperspectral image unmixing. Remote Sens. Environ. 2007, 108, 467-480.

27. Lewis, S.A.; Lentile, L.B.; Hudak, A. T.; Robichaud, P.R.; Morgan, P.; Bobbit, M.J. Mapping ground cover using hyperspectral remote sensing after the $2003 \mathrm{Simi}$ and Old wildfires in southern California. Fire Ecol. 2007, 3, 109-128. 
28. Adams, J.B.; Smith, M.O.; Johnson, P.E. Spectral mixture modeling: A new analysis of rock and soil types at the Viking Lander 1 Site. J. Geophys. Res. 1986, 91, 8098-8112.

29. Roberts, D.A.; Smith, M.O.; Adams, J.B. Green vegetation, nonphotosynthetic vegetation and soils in AVIRIS data. Remote Sens. Environ. 1993, 44, 255-269.

30. Smith, M.O.; Ustin, S.L.; Adams, J.B.; Gillespie, A.R. Vegetation in deserts: I. A regional measure of abundance from multi-spectral images. Remote Sens. Environ. 1990, 31, 1-26.

31. Townshend, J.R.G.; Huang, C.; Kalluri, S.N.V.; Defries, R.S.; Liang, S. Beware of per-pixel characterization of land cover. Int. J. Remote Sens. 2000, 21, 839-843.

32. Theseira, M.A.; Thomas, G.; Taylor, J.C.; Gemmell, F.; Varjo, J. Sensitivity of mixture modeling to end-member selection. Int. J. Remote Sens. 2003, 24, 1559-1575.

33. Byrne, G.F.; Crapper, P.F.; Mayo, K.K. Monitoring land-cover change by principal component analysis of multitemporal landsat data. Remote Sens. Environ. 1980, 10, 175-184.

34. Richards, J.A. Remote Sensing Digital Image Analysis: An Introduction, 2nd ed.; Springer-Verlag: New York, NY, USA, 1993; p. 340.

35. Lentile, L.B.; Morgan, P.; Hudak, A.T.; Bobbitt, M.J.; Lewis, S.A.; Smith, A.M.S.; Robichaud, P.R. Post-fire burn severity and vegetation response following eight large wildfires across the Western United States. Fire Ecol. 2007, 3, 91-108.

36. Key, C.H.; Benson, N.C. Landscape Assessment: Sampling and Analysis Methods. In FIREMON: Fire Effects Monitoring and Inventory System; Lutes, D.C., Ed.; RMRS-GTR-164-CD; Rocky Mountain Research Station, US Department of Agriculture, Forest Service: Fort Collins, CO, USA, 2006; pp. 219-273.

37. Bauer, D.F. Constructing confidence sets using rank statistics. J. Amer. Stat. Assn. 1972, 67, 687-690.

38. Hudak, A.T.; Morgan, P.; Bobbitt, M.J.; Smith, A.M.S.; Lewis, S.A.; Lentile, L.B.; Robichaud, P.R.; Clark, J.T.; McKinley, R.A. The relationship of multispectral satellite imagery to immediate fire effects. Fire Ecol. 2007, 3, 64-90.

39. Serrano-Ortiz, P.; Marañón-Jiménez, S.; Reverter, B.R.; Sánchez-Cañete, E.P.; Castro J.; Zamora, R.; Kowalski, A.S. Post-fire salvage logging reduces carbon sequestration in Mediterranean coniferous forest. For. Ecol. Manag. 2011, 262, 2287-2296.

40. Hudak, A.T.; Brockett, B.H. Mapping fire scars in a southern African savannah using Landsat imagery. Int. J. Remote Sens. 2004, 25, 3231-3243.

(C) 2012 by the authors; licensee MDPI, Basel, Switzerland. This article is an open access article distributed under the terms and conditions of the Creative Commons Attribution license (http://creativecommons.org/licenses/by/3.0/). 